\title{
Design and Study of Electrochemical Sensors Based on Polymer Inclusion Membranes Containing Polyoxometalates
}

\begin{abstract}
MIHAI APOSTU, MADALINA VIERIU, NELA BIBIRE*, ALINA DIANA PANAINTE, GLADIOLA TANTARU
Grigore T. Popa University of Medicine and Pharmacy lasi, Faculty of Pharmacy, Department of Analytical Chemistry, 16 University Str., 700115, lasi, Romania

Polyoxometalates (POM) are a class of inorganic compounds with various structures and remarkable electrical, magnetic and optical properties. Ion-pair complexes formed with some organic cations have high lipophilicity and they can be used as ionophores for PVC matrix membranes with active recognition function. The present study describes the construction and characterization of selective membrane sensors based on electroactive material incorporated in PVC matrix. They have been employed for the determination of ranitidine and nizatidine by using their complexes with silicotungstic acid as ionophores. The composition of the membrane has been optimized. The linear response range for both sensors was between $10^{-1}-10^{-5} \mathrm{M}$ with quantification limits of $2.83 \cdot 10^{-6} \mathrm{M}$ for ranitidine and $3.43 \cdot 10^{-6} \mathrm{M}$ for nizatidine, and a response time shorter than 50 seconds. The new electrodes have been used for the potentiometrical determination of ranitidine and nizatidine in pharmaceutical products.
\end{abstract}

Keywords: polyoxometalates, polymer inclusion membranes, electrochemical sensor, ranitidine, nizatidine

Polyoxometalates (POM) are a class of inorganic compounds that have attracted the interest of researchers since the nineteenth century due to their diversity and their properties. In 1826, Berzelius described their first representative, ammonium phosphomolybdate [1]. In 1933, Keggin determined through X-ray diffraction, the structure of phosphotungstic anion - $\left[\mathrm{PW}_{12} \mathrm{O}_{40}\right]^{3-}$ - that bears his name [2].

Polyoxometalates are aggregates, in general anionic, of transition metals (mainly $\mathrm{W}, \mathrm{Mo}, \mathrm{Nb}$ and $\mathrm{V}$ ) with oxygen, structured as clusters with metal-oxygen and metaloxygen-metal bonds. Those groups contain at least three atoms of the above-mentioned group, at their highest oxidation state, in combination with heteroatoms in heteropoloxymetalates or without heteroatoms such as $\mathrm{Si}, \mathrm{Ge}$ or $\mathrm{P}$ in isopolyoxometalates.

Almost any element can be incorporated into POM, leading to an overwhelming diversity of structures that can function as catalysts or that have antibacterial, antiviral, electrical, optical or magnetic properties [3-6].

Selective membrane sensors are a system in which a special membrane separates two electrolyte solutions containing different concentrations of the same chemical species. They function as transducers whose potential is a measure of the activity of the chemical species $[7,8]$.

The literature on the use of electrochemical sensors with specific response in the analysis of pharmaceuticals is particularly recent $[9,10]$. Selective membrane sensors based on electro-active material embedded in vinyl polychloride (PVC) matrix have the advantage of design, economy of active material and long service life [11, 12].

Silicotungstic anion (STA) is a heteropoloxometalate with high molecular weight that forms with many organic cations, ion-pair complexes with high lipophilicity that can be used as ionophores for PVC matrices with active recognition function [13-17].

The study presents the construction and characterization of selective membrane sensors with ionselective electrodes (ISE) for the determination of ranitidine (ISE-R) and nizatidine (ISE-N) using their complexes with silicotungstic acid as ionophores.

\section{Experimental part}

\section{Materials and methods}

Potentiometric measurements were carried out using a Hanna 301 pH/millivoltmeter. The ion-selective membrane electrode was used as indicator electrode in conjunction with an OP-0830P Radelkis saturated calomel electrode as reference electrode.

All reagents used while preparing the membranes were analytical reagent grade, produced by either Fluka or SigmaAldrich: polyvinyl chloride (PVC), silicotungstic acid (STA), o-nitrophenyloctyleter (o-NPOE), di(butyl)butyl-phosphonate (DBBP), dioctylphthalate (DOP), sodium tetraphenylborate (NaTPB) and tetrahydrofuran (THF).

\section{Synthesis of complexes}

Ranitidine and nizatidine (fig. 1) form amorphous light yellowish precipitates with silicotungstic acid (fig. 1) in acid medium.

Precipitation is achieved at $p \mathrm{H} 1.0$ and $50^{\circ} \mathrm{C}$ using $5 \%$ silicotungstic acid solution. After $60 \mathrm{~min}$ of rest at room temperature, the complexes were separated through filtration, washed with a saturated solution of the precipitate and then with distilled water, and dried to constant weight at room temperature in a vacuum desiccator.

X-ray diffraction analysis of ranitidine $[18,19]$ showed that the $\mathrm{N}$ atom in the dimethylamino group gets protonated $\left(\mathrm{pK}_{\mathrm{a}}=2.19\right)$. Nizatidine has an extra $\mathrm{N}$ atom in the protonated thiazole nucleus $\left(\mathrm{pK}_{\mathrm{a1}}=2.1, \mathrm{pK}_{\mathrm{a2}}=6.8\right.$ ) similar to famotidine [20]. The fact that famotidine $\left(\mathrm{pK}_{\mathrm{a}}=7.93\right)$ did not precipitate with silicotungstic acid led to the conclusion that the $\mathrm{N}$ atom of the thiazole nucleus was not involved in the complexation reaction.

The insoluble complexes were characterized through IR (JASCO FT/IR 670) and UV (HP 8540) spectroscopy, by determining their specific absorbance, solubility and melting points (table 1 ).

Interpretation of IR spectra was done through comparison to the spectra of the reactants, by attributing the main bands to the groups in the structure and following the changes in the molecules, which confirmed the complexation reaction.

\footnotetext{
* email: nela.bibire@umfiasi.ro
} 


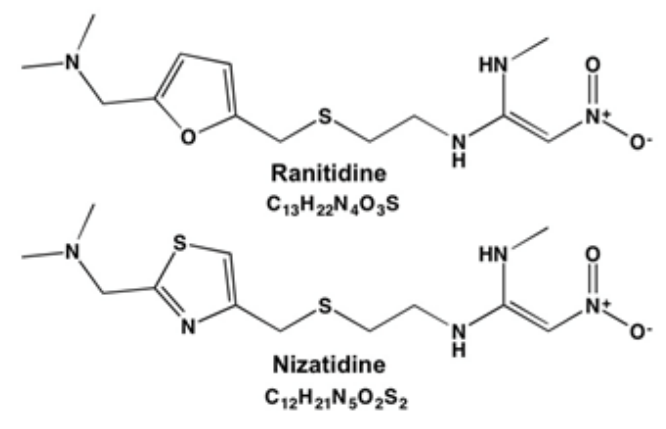

\begin{tabular}{|c|c|c|c|}
\hline Complex & $\mathbf{A}_{\mathrm{cm}}^{10 \%}$ & Solubility (g/L) & Melting point \\
\hline Ranitidine silicotungstate (R-STA) & $\begin{array}{c}63.01 \\
(\lambda=261 \mathrm{~nm})\end{array}$ & $8.1427 \cdot 10^{-3}$ & $\begin{array}{c}>350^{\circ} \mathrm{C} \\
\text { with decomposition }\end{array}$ \\
\hline Nizatidine silicotungstate (N-STA) & $\begin{array}{c}31.67 \\
(\lambda=264 \mathrm{~nm})\end{array}$ & $1.4928 \cdot 10^{-2}$ & $\begin{array}{c}>350^{\circ} \mathrm{C} \\
\text { with decomposition }\end{array}$ \\
\hline
\end{tabular}

\begin{tabular}{|c|c|c|c|c|}
\hline \multirow[t]{2}{*}{ Element $\%$} & \multicolumn{2}{|c|}{$\begin{array}{c}\text { R-STA } \\
{\left[\mathrm{C}_{13} \mathrm{H}_{23} \mathrm{~N}_{4} \mathrm{O}_{3} \mathrm{~S}_{4}-\left[\mathrm{SiW}_{12} \mathrm{O}_{40}\right]\right.}\end{array}$} & \multicolumn{2}{|c|}{$\begin{array}{c}\text { N-STA } \\
{\left[\mathrm{C}_{12} \mathrm{H}_{22} \mathrm{~N}_{5} \mathrm{O}_{2} \mathrm{~S}_{2}\right]_{4}-\left[\mathrm{SiW}_{12} \mathrm{O}_{40}\right]}\end{array}$} \\
\hline & Found & Calculated & Found & Calculated \\
\hline$\overline{\mathrm{C}}$ & 15.07 & 15.10 & 13.82 & 13.71 \\
\hline $\mathrm{H}^{-}$ & $2.16^{-}$ & $2.14^{-}$ & 2.10 & $2.01^{-}$ \\
\hline $\mathbf{N}$ & 5.50 & 5.42 & 6.81 & 6.66 \\
\hline
\end{tabular}

Elemental analysis (CE 440 Elemental Analyzer) confirmed the formation of 4:1 complexes of R- STA or NSTA respectively as shown in table 2 .

\section{Construction of electrodes}

Selective membranes were obtained by solubilizing the required amount of ionophore, PVC, plasticizer and additive in $5 \mathrm{~mL}$ THF. The solution was poured into a Petri dish ( 3 $\mathrm{cm}$ in diameter) covered with filter paper and the solvent was allowed to evaporate at room temperature for $24 \mathrm{~h}$.

A disc cut out from the membrane was attached to the end of a PVC tube ( $8 \mathrm{~mm}$ in diameter) using a PVC/THF mixture. $\mathrm{A} 10^{-3} \mathrm{M}$ solution of ranitidine or nizatidine dissolved in saturated $\mathrm{AgCl}$ solution was used as internal reference solution in which the internal $\mathrm{Ag} / \mathrm{AgCl}$ reference electrode was submerged. The $\mathrm{Ag} / \mathrm{AgCl}$ electrode was obtained by electrolysis using a Ag wire $(1 \mathrm{~mm} \times 50 \mathrm{~mm})$ as anode in combination with a Pt cathode immersed in a saturated $\mathrm{AgCl}$ solution and connected to a $9 \mathrm{~V} / 10 \mu \mathrm{A}$ direct current source.

Prior to use, the selective membrane electrode had been pre-conditioned by immersion in a $10^{-5} \mathrm{M}$ analyte salt solution for $120 \mathrm{~min}$. All potentiometric determinations were performed using the electrochemical cell shown in figure 2.

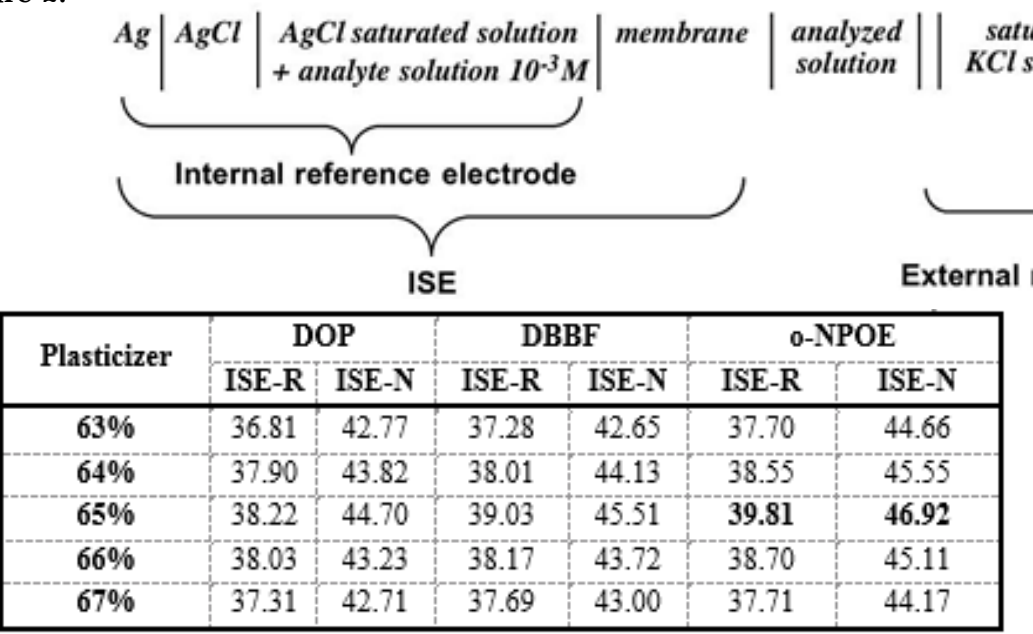

Fig. 1. Structures of ranitidine, nizatidine and silicotungstic acid

Table 1

SPECIFIC ABSORBANCE, SOLUBILITY AND MELTING POINT

Table 2

ELEMENTAL ANALYSIS OF COMPLEXES

\section{Results and discussions}

Optimization of membrane sensor composition

The optimal composition of the selective membrane was achieved by varying the mass ratio of the ionophore, PVC and plasticizer to the proportion that exhibited the best performance characteristics. The ionophore had to have suitable solubility in the membrane matrix, rapid exchange kinetics, high stability, and sufficient lipophilicity to prevent membrane transfer in the sample solution. The results of the potentiometric determinations showed that although changes were made regarding ionophore ratio to literature data, the plasticizer solubilized the ion pairs complex and its proportion regulated both membrane permeability and ion mobility in order to obtain the most selective and sensitive response [21]. Table 3 shows the slope of the electrodes (mV/decade) depending on the plasticizer used and its proportion.

The optimal composition for obtaining the most homogeneous, thin, elastic, mechanically resistant and best-response membranes is shown in table 4.

Fig. 2. Electrochemical cell

Table 3

OPTIMIZATION OF MEMBRANES COMPOSITION SLOPE ( $\mathrm{mV} /$ decade) (1-5\%), there was no significantleap in potential. According 


\begin{tabular}{|l|c|c|c|c|}
\hline Electrode & Ionophore & Plasticizer & Additive & Matrix \\
\hline ISE-R & R-STA (2.5) & o-NPOE (65) & NaTPB (1) & PVC (31.5) \\
\hline ISE-N & N-STA (2.5) & o-NPOE (65) & NaTPB (1) & PVC (31.5) \\
\hline
\end{tabular}

Table 4

MASS PERCENTAGE COMPOSITION OF PVC MATRIX IONSELECTIVE MEMBRANES

\section{Effect of $\mathrm{pH}$}

The effect of $p \mathrm{H}$ on electrode response was examined by measuring the variation of potential of the cell for three different solutions $\left(10^{-4}, 10^{-3}\right.$ and $\left.10^{-2} \mathrm{M}\right)$. Figure 3 shows the electrode response in the 1.0-10.0 pH range.

The electrode response was similar for all three concentrations levels and the optimal $\mathrm{pH}$ range was in between 1.0 and 5.0. There were slight interferences from the hydrogen ions at lower pH levels. In alkaline media, the membrane potential decreased due to the gradual precipitation of ranitidine or nizatidine in the measuring solution. Potential measurements were carried out after adjusting $\mathrm{pH}$ to 3.0 with buffer solution.

\section{Total ionic strength}

Because the electrodes responded to ionic activity, and the sought result was the concentration of the analyte, it was important to keep the activity coefficient constant for all solutions. It was necessary to achieve a constant and relatively high concentration of a high purity electrolyte to which the selective membrane did not respond.

A 0.1 value of the ionic strength $(\mathrm{m})$ was found to be optimum for samples with concentration below $10^{-2} \mathrm{M}$ and it was obtained through dilution using $\mathrm{KNO}_{3} 1 \mathrm{M}$. The measured potential of $10^{-2}$ and $10^{-1} \mathrm{M}$ solutions was not influenced by the ionic strength.

\section{Response time}

The determination of the response time was always done using an assay sequence from low to high concentrations. The electrode response stabilized after 4050 seconds for solutions with concentration lower than $10^{-2} \mathrm{M}$ and it was virtually instantaneous for those more concentrated.

Experimental data obtained were subjected to statistical processing, establishing for each constructed electrode its linear response range, limit of quantification, precision, accuracy, selectivity and robustness of the method.

\section{Linearity}

The electrodes response was studied in the concentration range between $10^{-7}-10^{-1} \mathrm{M}$ at $\mathrm{pH} 3.0$ and 0.1 ionic strength $(E=m V, C=m o l / L, p C=-\log C)$. For each electrode the concentration range of linear relationship between the measured potential and the concentration of the analyzed ion was determined (table 5).

A graphical method was applied for calculating the limit of quantification (LOQ) defined as the intersection of the regression line for the linear domain with the range when the electrode response was relatively constant (fig. 4.).

\section{Precision}

The precision of the method was studied in terms of repeatability and reproducibility. Two series of measurements have been done in different days for three different concentration levels $\left(10^{-4}, 10^{-3}\right.$ and $\left.10^{-2} \mathrm{M}\right)$ of the analyte. For each concentration level three determinations series were carried out (table 5).

\section{Accuracy}

The accuracy of the electrodes was assessed by analyzing three standard solutions with analyte concentration of $10^{-4}, 10^{-3}$ and $10^{-2} \mathrm{M}$, respectively. The correspondence betw een the real and the analytical result obtained from measurements was evaluated by calculating the relative error - $X \mathrm{~d}(\%)$, using the equation (1):

$$
X d(\%)=\frac{|X r-X a|}{X a} \cdot 100
$$

where $\mathrm{Xr}$ was the value calculated from the calibration curve for the theoretical value Xa (table 5).
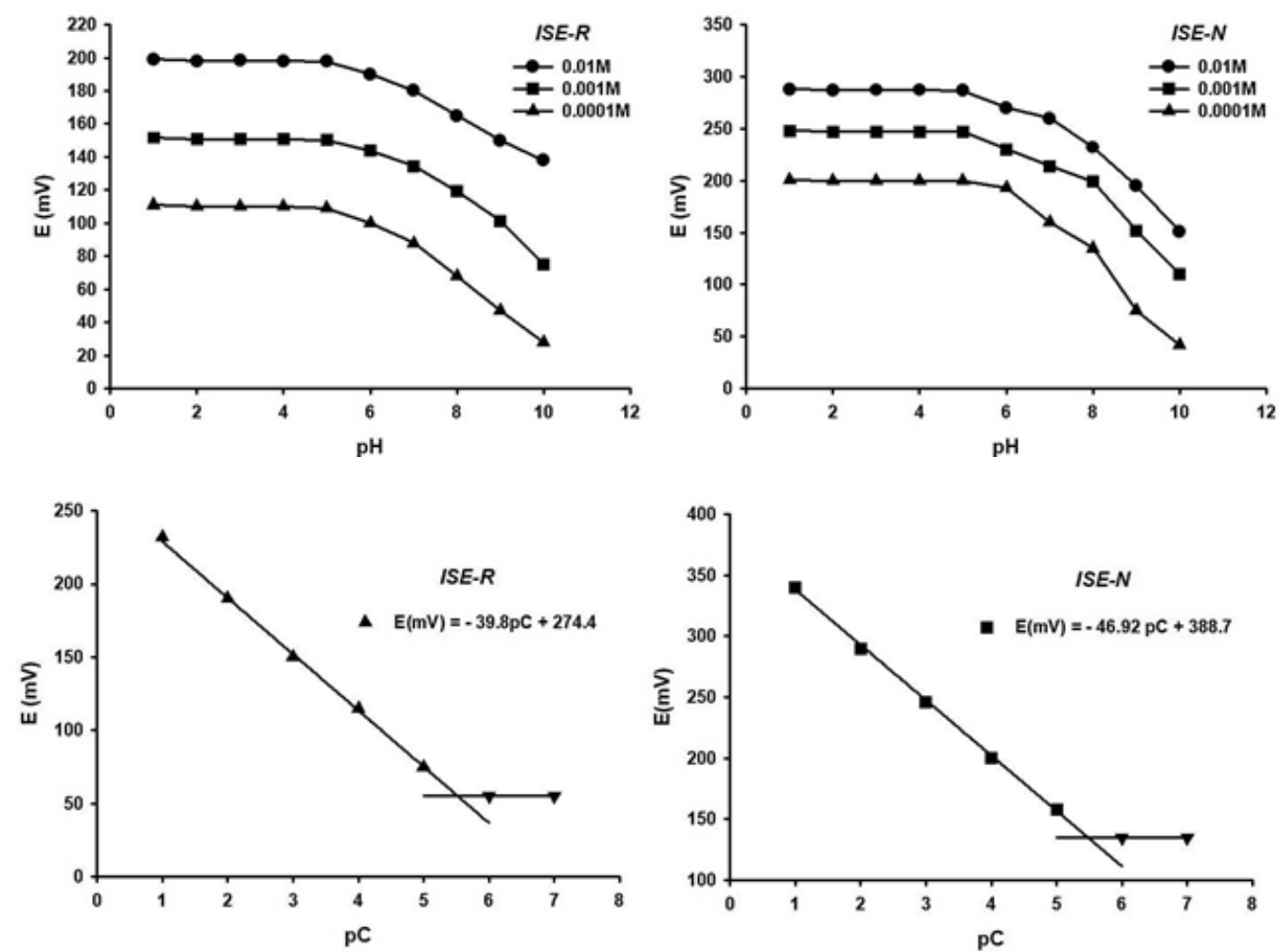

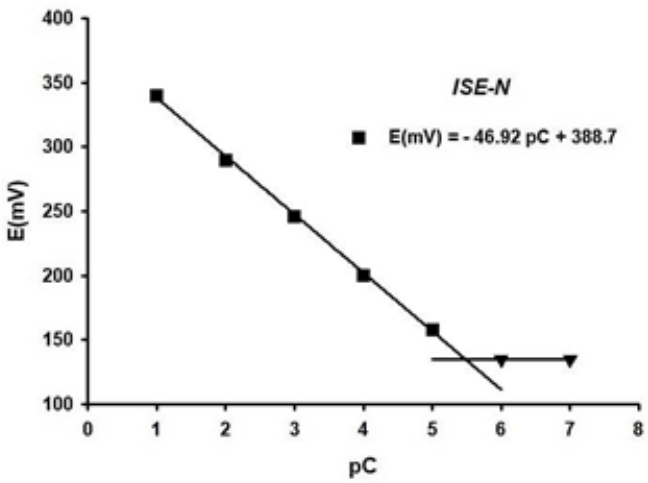

http://www.revmaterialeplastice.ro
Fig. 3. Effect of $p H$ on electrode response

Fig. 4. LOQ and calibration curves for ISE-R and ISE-N 


\begin{tabular}{|c|c|c|c|}
\hline \multicolumn{2}{|l|}{ Electrode } & ISE-R & ISE-N \\
\hline \multicolumn{2}{|l|}{ Linearity range } & $10^{-1}-10^{-5} \mathrm{M}$ & $10^{-1}-10^{-5} \mathrm{M}$ \\
\hline \multicolumn{2}{|c|}{ Regression equation } & $\mathrm{E}=-39.81 \cdot \mathrm{pC}+277.4$ & $\mathrm{E}=-46.92 \cdot \mathrm{pC}+388.7$ \\
\hline \multicolumn{2}{|c|}{ Regression coefficient $\left(\mathrm{r}^{2}\right)$} & 0.9954 & 0.9939 \\
\hline \multicolumn{2}{|l|}{ Slope (P) } & $39.81 \mathrm{mV} /$ decade & $46.92 \mathrm{mV} /$ decade \\
\hline \multicolumn{2}{|c|}{ Standard deviation $(\sigma)$} & 0.4676 & 0.5403 \\
\hline \multicolumn{2}{|l|}{ LOQ } & $2.83 \cdot 10^{-6} \mathrm{M}$ & $3.43 \cdot 10^{-6} \mathrm{M}$ \\
\hline \multirow{2}{*}{$\begin{array}{l}\text { Repeatability } \\
\text { Its Series }^{\text {st }}\end{array}$} & SD & 3.11 & 2.09 \\
\hline & RSD & $3.17 \%$ & $2.14 \%$ \\
\hline \multirow{2}{*}{$\begin{array}{l}\text { Repeatability } \\
\text { II }{ }^{\text {dd }} \text { Series }\end{array}$} & SD & 3.31 & 1.97 \\
\hline & RSD & $3.36 \%$ & $2.01 \%$ \\
\hline \multirow{2}{*}{ Reproducibility } & SD & 3.20 & 1.98 \\
\hline & RSD & $3.25 \%$ & $2.04 \%$ \\
\hline Accuracy & $\overline{X d}$ & $3.26 \%$ & $2.19 \%$ \\
\hline
\end{tabular}

Table 5

VALIDATION PARAMETERS OF THE POTENTIOMETRIC METHODS

\section{Robustness}

Robustness was tested by investigating the ability of the proposed methods to remain unaffected by small but deliberate changes in the working parameters, thus providing an indication of their reliability during normal use. The degree of reproducibility of the results was investigated by analyzing the same samples under various conditions, such as different analysts and tools. The results obtained on the same samples by another analyst using another $\mathrm{pH}$ meter model (Orion 420A) were compared to those obtained using the Hanna $301 \mathrm{pH}$-meter. The recorded potentials were very close, thus confirming the validity of the method.

\section{Electrode selectivity}

The selectivity of electrodes (table 6) was investigated using the separate solution method [22] and the potentiometric selective coefficients $(\mathrm{K})$, were calculated using the following equations:

$$
\begin{gathered}
\log K=\frac{E_{(I I)}-E_{(I)}}{P}+\log \left[A^{y+}\right]-\log \left[I^{z+}\right] \\
K=10^{\frac{\Delta E}{P}} \cdot \frac{\left[A^{y+}\right]}{\left[I^{z+}\right]}
\end{gathered}
$$

Two separate solutions of the same concentration (10$\left.{ }^{3} \mathrm{M}\right)$ were prepared for the primary ion $\left(\mathrm{A}^{\mathrm{y}+}\right)$ and the interfering secondary ion $\left(\mathrm{I}^{\mathrm{z}}\right)$. Their potentials $\mathrm{E}_{1}\left(\right.$ for $\left.\mathrm{A}^{\mathrm{y}+}\right)$ and $E_{\|}\left(\right.$for $I^{z+}$ ) were measured ( $P$ - slope of the calibration curve). The separate solution method is one of the methods recommended by IUPAC [23].

Ranitidine, famotidine and nizatidine interfere with each other's analysis on a reduced level in terms of electrode response. Since there are no pharmaceuticals products containing any association of those three drugs, it is highly unlikely that those interferences will actually occur. The cations present in the excipients commonly used in the formulation of the tablets/capsules did not interfere.

\section{Service life and membrane regeneration}

The electrodes constantly used during the experiment had an average service life of approximately $35 \pm 2$ days. Preconditioning the electrodes by immersion in the analyte solution or their use for large series of determinations had a negative effect on the electrode response. The ionophore regeneration from the outer membrane gel layer ( produced by hydration) was attempted by immersing the exhausted electrode for $24 \mathrm{~h}$ in a $5 \%$ silicotungstic acid solution followed by immersion for $2-3 \mathrm{~h}$ in a $10^{-1} \mathrm{M}$ solution of ranitidine or nizatidine. The service life of the regenerated electrode did notexceed 10 determinations due to the ease of ionophore transfer from the gel layer of the outer surface of the membrane into the sample solution, process that occurred slowly to the ionophore set in the PVC matrix in the initial membrane construction process.

\section{Pharmaceutical applications}

The constructed and characterized sensors were used to determine by direct potentiometry ranitidine and nizatidine from pharmaceutical products (injectable solutions, tablets and capsules). The results obtained fell within the limits set by the Romanian Pharmacopoeia $X^{\text {th }}$ edition (RPX), regarding the accepted content variation of active substance depending on the labeled dose (table 7).

Table 6

\begin{tabular}{|c|c|c|c|c|c|}
\hline Interferer & $\overline{\text { ISE-R }}$ & $\overline{\text { ISE-N }}$ & Interferer & ISE-R & $\overline{\text { ISE-N }}$ \\
\hline $\mathrm{NH}_{4}^{+}$ & $2.10 \cdot 10^{-4}$ & $9.34 \cdot 10^{-5}$ & Ranitidine & - & $1.60 \cdot 10^{-1}$ \\
\hline $\mathrm{Na}^{--}$ & $1.30 \cdot 10^{-4}$ & $2.76 \cdot 10^{-4}$ & Famotidine & $1.76 \cdot 10^{-4}$ & $3.32 \cdot 10^{-2}$ \\
\hline $\mathrm{Ca}^{+2}$ & $3.50 \cdot 10^{-5}$ & $8.95 \cdot 10^{-5}$ & Nizatidine & $2.46 \cdot 10^{-1}$ & - \\
\hline $\mathbf{M g}^{+I^{-}}$ & $6.54 \cdot 10^{-4}$ & $7.36 \cdot 10^{-4}$ & $\mathbf{Z n}^{-5}$ & $3.24-10^{-2}$ & $5.16 \cdot 10^{-4}$ \\
\hline $\mathbf{A l}^{+s}$ & $1.35 \cdot 10^{-4}$ & $3.35 \cdot 10^{-4}$ & $\mathrm{Fe}^{+3}$ & $1.62 \cdot 10^{-4}$ & $4.05 \cdot 10^{-4}$ \\
\hline
\end{tabular}

SELECTIVITY COEFFICIENT (K)

Table 7

\begin{tabular}{|c|c|c|c|c|c|c|}
\hline \multirow{2}{*}{ Drug } & \multicolumn{3}{|c|}{ Tablets/capsules } & \multicolumn{3}{|c|}{ Injectable solution } \\
\hline & Labeled & Found & RPX & Labeled & Found & $\mathrm{RPX}^{-}$ \\
\hline $\begin{array}{c}\text { Ranitidine } \\
(n=6)\end{array}$ & $75 \mathrm{mg}$ & $74.46 \pm 0.29 \mathrm{mg}$ & $75 \pm 5.62 \mathrm{mg}$ & $50 \mathrm{mg} / 2 \mathrm{~mL}$ & $\begin{array}{c}49.37 \pm 0.22 \\
\mathrm{mg} / 2 \mathrm{~mL}\end{array}$ & $50 \pm 2.50 \mathrm{mg}$ \\
\hline $\begin{array}{l}\text { Nizatidine } \\
(n=6)\end{array}$ & $300 \mathrm{mg}$ & $\begin{array}{c}300.40=0.27 \\
\mathrm{mg}\end{array}$ & $300 \pm 15.0 \mathrm{mg}$ & $100 \mathrm{mg} / 4 \mathrm{~mL}$ & $\begin{array}{c}100.48=0.26 \\
\mathrm{mg} / 4 \mathrm{~mL}\end{array}$ & $100 \pm 5.00 \mathrm{mg}$ \\
\hline
\end{tabular}

DIRECT POTENTIOMETRIC DETERMINATIONS FROM PHARMACEUTICAL PRODUCTS 


\section{Conclusions}

Two potentiometric sensors have been constructed based on ion pair complexes of ranitidine and nizatidine with silicotungstic acid as ionophores. The electroactive compound was dispersed in a PVC matrix using 0nitrophenyloctyl ether as plasticizer. The main functional characteristics of the sensors were studied and they were used for the assay of ranitidine and nizatidine in the $10^{-1}-10$ ${ }^{5} \mathrm{M}$ concentration range, with a response time lower than $50 \mathrm{~s}$. The methods proposed for the determination of ranitidine and nizatidine in pharmaceutical forms were fast, simple, accurate and inexpensive.

\section{References}

1. BERZELIUS, J. J., Pogg. Ann. Phys. Chem., 6, 1826, p. 369.

2. KEGGIN, J.F., Nature, 132, 1933, p. 351.

3. KAMIYA, Y., SADAKANE, M., UEDA, W., Heteropoly Compounds. In: Comprehensive Inorganic Chemistry II, Elsevier, Amsterdam, 2013, p. 185.

4. VAN ELDIK, R., CRONIN, L., Polyoxometalate Chemistry. In: Advances in Inorganic Chemistry, Academic Press, Cambridge, 2017, p. 2.

5. TANTARU, G., APOSTU, M., Rev. Chim. (Bucharest) 61, no. 7, 2010, p. 632.

6. TANTARU, G., MARIN, L., VIERIU, M., PANAINTE, A.D., POIATA, A., APOSTU, M., BIBIRE, N., Rev. Chim. (Bucharest) 66, no. 12, 2015, p. 1965.

7. KRISTENSEN, M.B., BENTIEN, A., TEDESCO, M., CATALANO, J., J. Colloid. Interface Sci., 504, 2017, p. 800.

8. SHUJ AHADEEN, B.A., THOMPSON, J.W., KADIR, M.F.Z., HAMEED, M.A., J Sci. Adv. Mater. \& Dev., 3, 2018, p. 1.
9. COSOFRET, V.V., BUCK, R.P., Pharmaceutical Applications of Membrane Sensors, CRC Press, Boca Raton, 2017.

10. INES, M., ALMEIDA, G.S., CATTRALL, R.W., KOLEV, S.D., Anal. Chim. Acta, 987, 2017, p. 1.

11. APOSTU, M., BIBIRE, N., TANTARU, G., VIERIU, M., PANAINTE, A.D., AGOROAEI, L., Rev. Chim. (Bucharest), 66, no. 5, 2015, p. 657. 12. APOSTU, M., BIBIRE, N., VIERIU, M., PANAINTE, A.D., TANTARU, G., Rev. Chim. (Bucharest), 64, no. 7, 2013, p. 781.

13. SHANMUGAM, S., VISWANATHAN, B., VARADARAJ AN, T.K., J. Membr. Sci., 275, 2006, p. 105.

14. FERNANDES, D.M., CHRISTOPHER, M.A.B., CAVALEIRO, A.M.V., J. Electroanal. Chem., 660, 2011, p. 50.

15. ABU SHAWISH, H.M., SAADEH, S.M., AL-DALOU, A.R., ABU GHALWA, N., ABOU ASSI, A.A., Mater. Sci. Eng. C, 31, 2011, p. 300.

16. KHATER, M.M., ISSA, Y.M., HASSIB, H.B., MOHAMMED, S.H., J. Adv. Res., 6, 2015, p. 459.

17. EL-TOHAMY, M., RAZEQ, S., EL-MAAMLY, M., SHALABY, A., Cent. Eur. J. Chem., 8, no. 4, 2010, p. 937.

18. TOSHIMASA I., YASUKO I., MASATOSHI I., Acta Cryst., C46, 1990, p. 1893.

19. HUQ, A., STEPHENS, P.W., J. Pharm. Sci., 92, no. 2, 2003, p. 244. 20. BASAVAIAH, K., ZENITA, O., Quim. Nova, 34, no. 5, 2011, p. 735. 21. ZAREH, M.M., Recent advances in plasticizers. In: Plasticizers and their role in membrane selective electrodes, Ed. InTech, London, 2012, p. 113.

22. SRINIVASAN, K., RECHNITZ, G.A., Anal. Chem., 41, no. 10, 1969, p. 1203.

23. UMEZAWA, Y., BUHLMANN, F., UMEZAWA, K., TOHDA, K., AMEMIYA, S., Pure Appl. Chem., 72, no. 10, 2000, p. 1851.

Manuscript received: 3.02 .2019 